\title{
Transformation of the Forest-based Bioeconomy by Embracing Digital Solutions
}

\author{
Chihiro Watanabe ${ }^{1,2}$ \\ Nasir Naveed ${ }^{1}$ \\ Kashif Naveed ${ }^{1}$ \\ Pekka Neittaanmäki ${ }^{1}$ \\ ${ }^{1}$ Faculty of Information Technology, University of Jyväskylä, Finland. \\ ${ }^{2}$ International Institute for Applied Systems Analysis (IIASA), Austria.
}

\begin{abstract}
This paper attempts to explore a new insight to both industrialized and growing economies by demonstrating a digital-driven creative disruption in the forest-based bioeconomy which is beginning to replace its conventional and narrow concept of a forest-blinded economy.

Notwithstanding the potential broad cross-sectoral benefits to both industrialized and growing economies, natural environments and locality constraints and the incessant challenge of distance have impeded balanced development of this economy.

However, driven by digital solutions the economy has taken big steps forward in recent years. Digitalization has enabled real-time end-to-end supply chain visibility, improved delivery accuracy, stock level optimization and alignment with demand planning. These have led to digital ecosystem collaboration and a transparency crossover industrialized and growing economies worldwide. Thus, creative disruptive platform has emerged by embracing digital solutions.

By means of an empirical analysis focusing on the noteworthy business activities at the forefront of both upstream and downstream of the chain, this paper demonstrates a transforming stream observed in the forefront of a forest-based bioeconomy chain.

This research thus explores a new insight common to both industrialized and growing economies in constructing a creative disruption platform by embracing digital solutions.
\end{abstract}

Keywords: Forest-based bioeconomy; Transformation; Digital solutions; Creative disruption platform; Amazon business model.

\section{INTRODUCTION}

The forest-based bioeconomy is beginning to replace its conventional and narrow concept of a forest-blinded economy. The forest-based bioeconomy is an important sub-sector of the bio-based economy where forests are anticipated to deliver a significant contribution of biomass (Hetemaki, 2014; Scarlat et al., 2015). A bio-based economy can be defined as one using "production paradigms that rely on biological processes and, as with natural ecosystems, use natural inputs, expend minimum amounts of energy and do not produce waste as all materials discarded by one process are inputs for another process and are reused in the ecosystem." (Nebe, 2011).

Journal of Technology Management for Growing Economies Vol. 8, No. 2 October, 2017 pp. 191-214

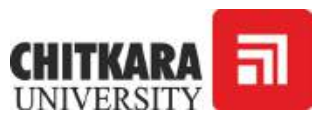

(C)2017 by Chitkara University. All Rights Reserved. 
Watanabe, C.

Naveed, N.

Naveed, K.

Neittaanmäki, P.

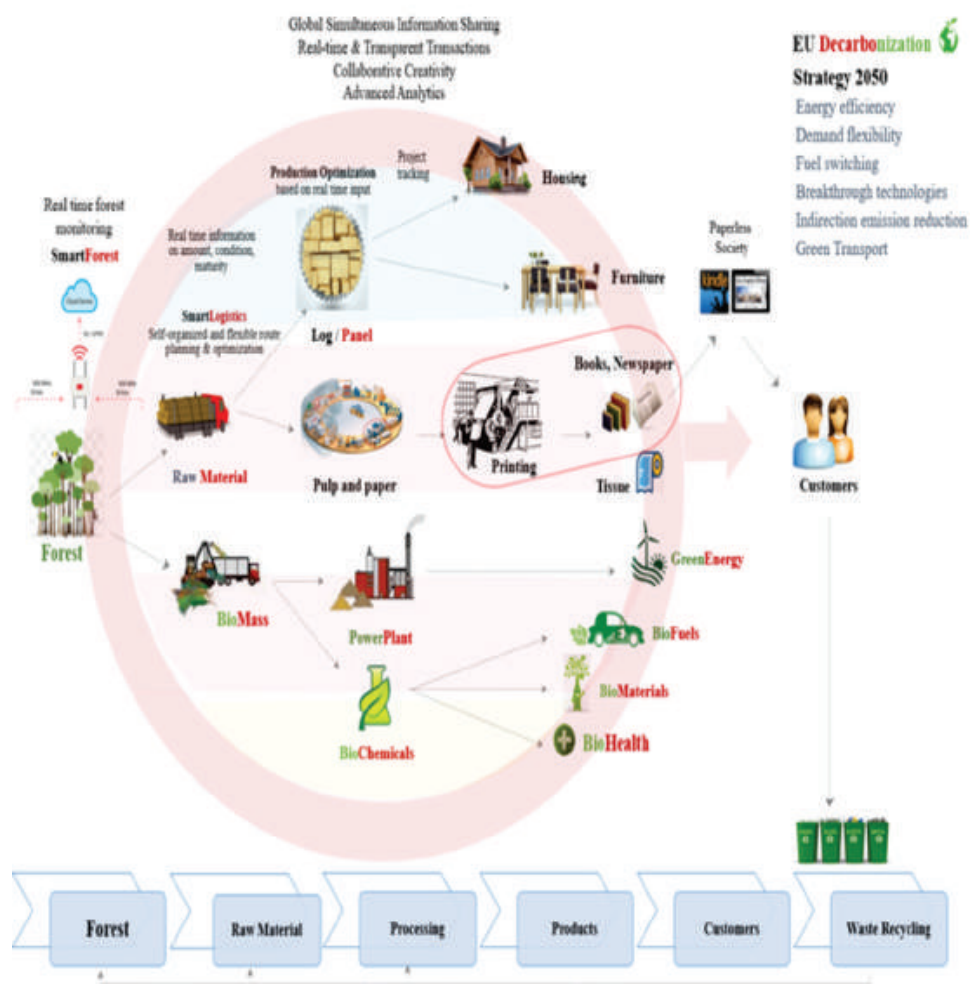

Figure 1: Transformation of Value Chain in Forest-based Bioeonomy.

Source: Made by Authors based on CEPI, 2015.

However, notwithstanding the potential broad cross-sectoral benefits to both industrialized and growing economies, natural environments and locality constraints and the incessant challenge of distance have impeded balanced development of this economy. Thus, digital solutions that may enable real-time global information sharing, and transparent transactions, collaborative creativity, and advanced analytics (Poyry, 2017).

To understand the changes in forest or environmental sustainability, it requires the consideration of forest-based products such as books, magazines, buildings, furniture, food, textile, packages and so on (Hetemäki, 2014). Within the forest-based bioeconomy of Europe, pulp and paper is an important industry which accounts for approximately 150 million cubic meter of wood consumption annually and adds 15 billion euros to the Gross Domestic Product (GDP) of European Union. (CEPI, 2014). Moreover, Pulp and paper industry accounts for $2 / 3$ of the total production value of the Finnish forest industry as illustrated in Fig. 


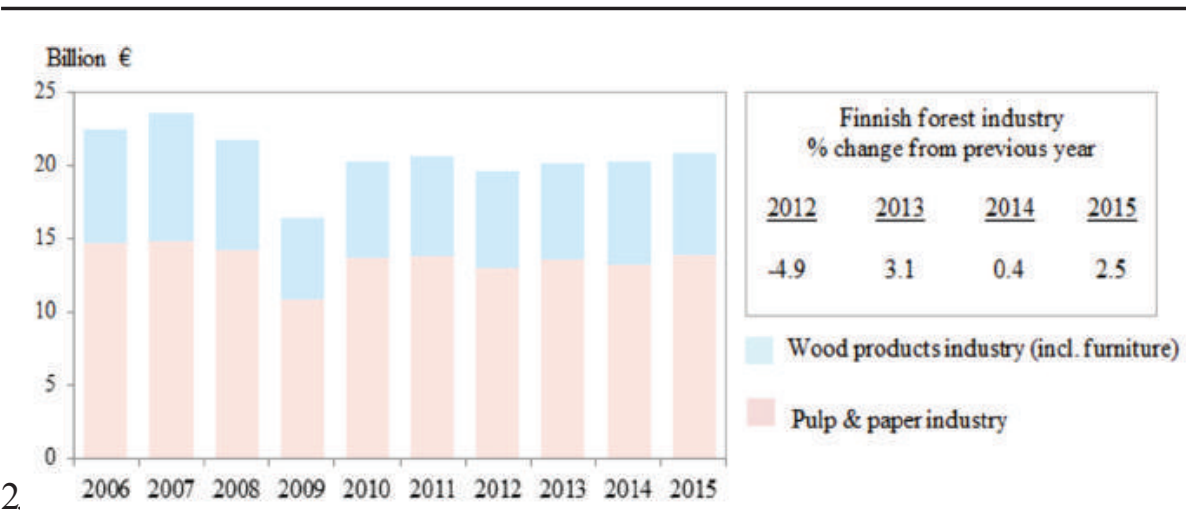

Transformation of the Forestbased

Figure 2: Gross Value of Finnish Forest Industries (2006 - 2015).

Source: Statistics Finland (annual issues).

\section{Transformation of Forest-based Bioeconomy}

Currently, European pulp and paper industry is undergoing the transformation due to changing customer needs and market dynamics under increased global competition and policies. Latin America and Southeast Asia have intensified the competition with low cost of production for pulp and paper respectively.

In order to stay competitive, pulp and paper industries need to innovate their business models, products, services and processes. Consequently, digital solutions carry huge potential to transform the industry (CEPI, 2015). Pulp and paper industry constitutes sophisticated global value chain consisting of upstream chain and downstream chain as illustrated in Fig. 3.

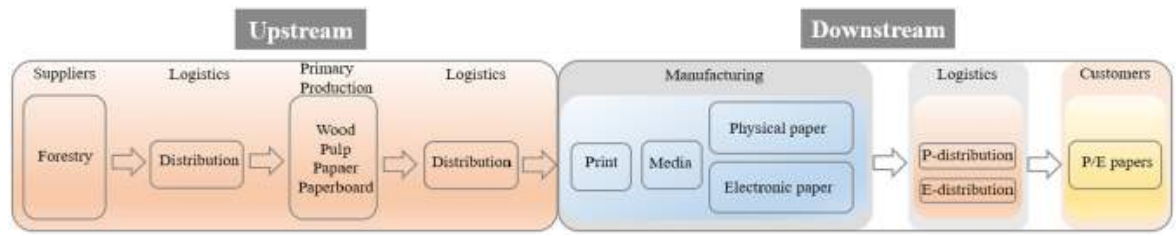

Figure 3: Value Chain of Forest-based Bioeconomy focusing on Pulp and Paper Industry

Source: Authors'elaboration based on (Beamon, 1998).

The upstream value chain attributes to the raw material from forest to primary production of wood, pulp, paper and paperboard while the downstream value chain attributes to the manufacturing of printing paper to the final products for the customers. Fig. 4 illustrates global leaders in upstream and downstream in forest-based bioeconomy in 2015. 
Watanabe, $\mathrm{C}$.

Naveed, N.

Naveed, K.

Neittaanmäki, P.

194

\section{Paper \& Paperboard Production}

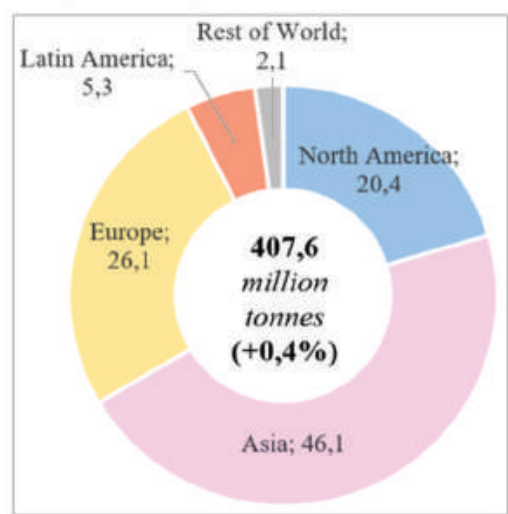

\section{Paper \& Paperboard Consumption}

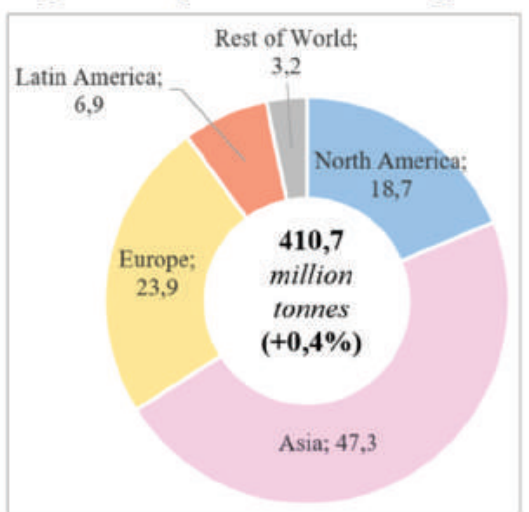

Figure 4: Global Leaders in Upstream and Downstream in Forest-based Bioeconomy (2015).

Source: CEPI (2017).

It is evident from the Fig. 4, Asia accounts for the largest share both in production and consumption, and they are depending on traditional system. Contrary to Asia, Europe (particularly Finland) and the US take pivotal role in digital solutions leading them leaders of upstream and downstream for digital solutions (CEPI, 2015) . Figs. 5 and 6 demonstrate trends in production and consumption of paper and paper products in the world over the last five decades. Figs. 5 and $\mathbf{6}$ demonstrate trends in production and consumption of paper and paper products in the world over the last five decades. Fig. 5 highlights also trends in Finland as a leading upstream country in the value chain (See Appendix 1 yearly statistics over the period 1961-2015).
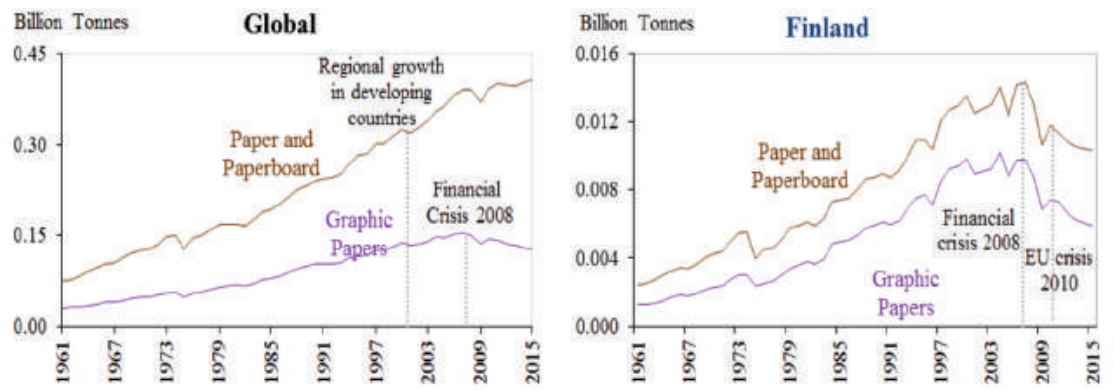

Figure 5: Trends in Production of Paper Products - Global and Finland (1961-2015).

Source: Forestry and Agriculture Organization (2016). 


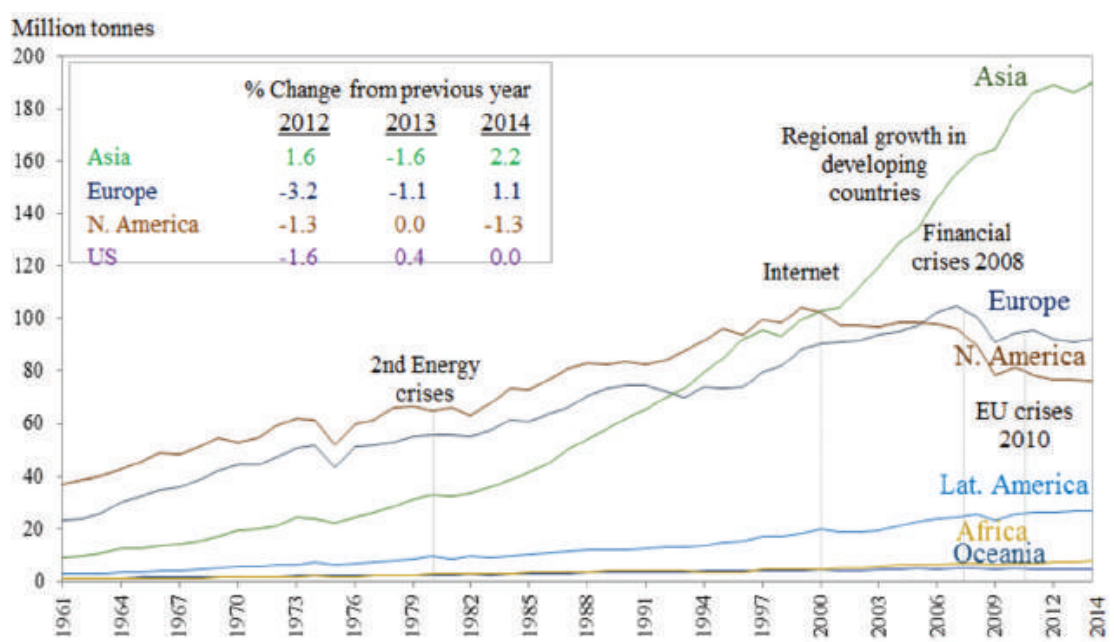

Transformation of the Forestbased

Figure 6: Trends in Paper and Paperboard Consumption by Global Regions

(1961-2014)

Source: Finnish Forest Industries (2016).

These Figures suggest that global structure of production and consumption of paper and paper products has dramatically changed after the Lehman shock in 2008 particularly in Europe and North America. While global production of paper and paper products continued to steady growth initiated by these global leaders corresponding to consumption increase before the Lehman shock, these initiatives were substituted by emerging economies, particularly by Asia.

In addition to economic stagnation after the Lehman shock in 2008, increasing concern to de-carbonization has accelerated consumption decline in global leaders and subsequent production decrease in these leaders as typically observed in Finland which shares 6-8\% global pulp production. Such a balanced decline in global leaders corresponds to digitalization of economy as clearly observed in North America which demonstrates explicit production decline corresponding to the net bubble bursting in 2000 .

However, if we look at Fig. 6 together with Fig. 2 (and also Figs. 12-2 and 13 in the next section) carefully, we note that decreasing pace in production in Europe and North America have stagnated and signature of resurgence can be observed very recently (PTT, 2016). This resurgent possibility inspires us a hope of digital solutions to the long-lasting impediments of the forest-based bioeconomy.

Notwithstanding the potential broad cross-sectoral benefits to both industrialized and growing economies, natural environments and locality constraints and the incessant challenge of distance have impeded balanced development of the forest-based bioeconomy. However, recent advancement of 
Watanabe, $\mathrm{C}$. Naveed, N. Naveed, K. Neittaanmäki, P. digitalization has enabled real-time end-to-end supply chain visibility, improved delivery accuracy, stock level optimization and alignment with demand planning. These may lead to digital ecosystem collaboration and a transparency crossover industrialized and growing economies worldwide. Thus, creative disruptive platform can be emerged by embracing digital solutions.

To date, many studies analyzed value chain of the forest-based bioeconomy (Hetemaki, et al. 2014; Toppinen et al., 2017; Mustalahti, 2017; Wolfslehner et al., 2016; Giurca, A. 2017; Hetemaki, 2016; Pelli et al., 2017) from different dimensions. For example, Hetemaki, et al., 2014 described the European forestbased sector as a creative destruction. Toppinen et al., 2017 attempted how the pulp and paper industry may transform strategically, and possible potential for value creation. Mustalahti, 2017 focused on the conceptual understanding of responsive governance of the forest-based bioeconomy by describing the need for inclusion of citizens and environmental capability in the forest-based bioeconomy. The study conducted by Wolfslehner et al., 2016 gave insights on the potential use of forest-based indicator sets in Europe and how bioeconomy indicators can be designed in the future. Giurca, A. 2016 in his study attempted to describe the forest-based bioeconomy for Germany as well as strengths, weaknesses and policy options for lignocellulosic biorefineries. Although various studies are available on the forest-based bioeconomy however, none has undertaken the analysis from the view point of creative disruption platform by embracing the digital solution and encompassing the whole value chain of pulp and paper industry from up-stream to downstream.

The objective of this paper is to analyze the transformation of forest-based bioeconomy and it explores new insights common to both industrialized and growing economies in constructing a creative disruption platform by embracing digital solutions. This paper conducts an empirical analysis by focusing on the noteworthy business activities in the case leading firms UPM and Amazon positioned at the forefront of upstream and downstream of the chain respectively.

The structure of paper is as follows: Section 2 analyzes structural change in supply chain of the forest-based bioeconomy. Perspectives of transformation towards creative disruption platform is presented in Section 3. Section 4 briefly summarizes noteworthy findings, implications, and suggestions for future works.

\section{STRUCTURAL CHANGE IN SUPPLY CHAIN}

\section{Transformation of Forest-based Bioeconomy}

\section{Supply Chain Embracing Digital Solutions}

Given a possible digital solutions to the impediments of forest-based economy, it can be attributed to the maturity of the following conditions:

Journal of Technology Management for Growing Economies, Volume 8, Number 2, October 2017 
(i) Sophisticated global value chain of pulp and paper industry consisting of upstream and downstream chains,

(ii) Inspiring interactions between upstream and downstream chains, and

(iii) Embracing capacity of digital innovation in each respective players of the chain.

Fig. 7 illustrates structure of the value chain that enables to embrace the advancement of digital innovation.

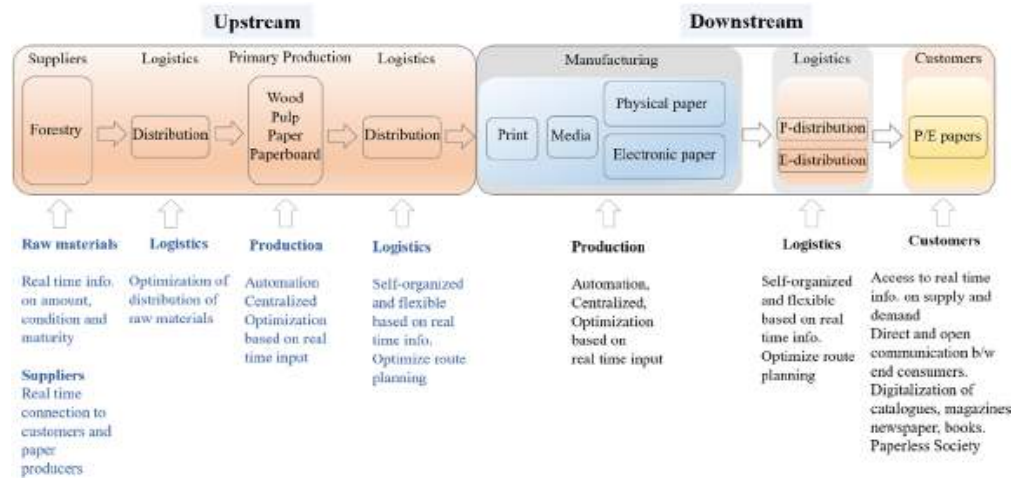

Figure 7: Value Chain Structure of Forest-based Bioeconomy focusing on Pulp and Paper Industry

Source: Authors' elaboration based on (Beamon, 1998) and (CEPI, 2015)

With such structure that enables to embrace the advancement of digital innovation, digital solutions as illustrated in Fig. 8 have incorporated in the value chain thereby transformation of forest-based bioeconomy has been enabled.
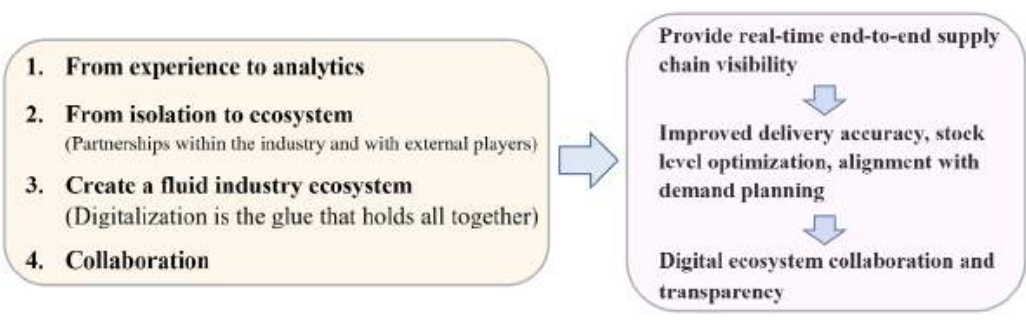

Figure 8: Digital Solutions Enabling Supply Chain Transformation in Forestbased Bioeconomy.

Original source: Tieto (2017).

\section{Structural Change in Downstream}

\section{(1) Market Structure}

Aiming at analyzing structural change in downstream of the forest-based bioeconomy as a consequence of transformation toward digital solutions, 
Watanabe, $\mathrm{C}$. Naveed, N.

Naveed, K.

Neittaanmäki, P.

198
Table 1 and Fig. 9 review trends in sales volume, sales revenues and prices of books by types in the US.

Table 1: Trends in Sales Volume, Sales Revenues and Prices of Books by

Types in the US (2004-2015)

\begin{tabular}{|c|c|c|c|c|c|c|c|c|c|c|c|}
\hline & \multicolumn{3}{|c|}{ Revenues (millions) } & \multicolumn{3}{|c|}{ Quantity Unit (millions) } & \multicolumn{5}{|c|}{ Price/Unit } \\
\hline Year & P-book & E-book & Total & P-book & E-book & Total & P-book & Change rate & E-book & Change rate & Total \\
\hline 2002 & 3897,7 & 2,10 & 3899,80 & & & & & & & & \\
\hline 2003 & 3838,3 & 6,00 & 3844,30 & & & & & & & & \\
\hline 2004 & 3794,7 & 9,30 & 3804,00 & 648 & & 648 & 5,86 & & & & 5,87 \\
\hline 2005 & 5058,5 & 16,00 & 5074,50 & 710 & & 710 & 7,12 & & & & 7,15 \\
\hline 2006 & 5036,4 & 25,20 & 5061,60 & 721 & & 721 & 6,99 & & & & 7,02 \\
\hline 2007 & 5457,9 & 31,70 & 5489,60 & 758 & & 758 & 7,20 & & & & 7,24 \\
\hline 2008 & 5158 & 61,30 & 5219,30 & 778 & & 778 & 6,63 & & & & 6,71 \\
\hline 2009 & 5127 & 169,50 & 5296,50 & 770 & 64 & 834 & 6,66 & & 2,65 & & 6,35 \\
\hline 2010 & 4864 & 441,30 & 5305,30 & 718 & 69 & 787 & 6,77 & & 6,40 & & 6,74 \\
\hline 2011 & 5506,8 & 1097,60 & 6604,40 & 651 & 165 & 816 & 8,46 & & 6,65 & & 8,09 \\
\hline 2012 & 5476,1 & 1551,20 & 7027,30 & 592 & 215 & 807 & 9,25 & $9,35 \%$ & 7,21 & $8,46 \%$ & 8,71 \\
\hline 2013 & 5374,9 & 1547,20 & 6922,10 & 620 & 242 & 862 & 8,67 & $-6,28 \%$ & 6,39 & $-11,39 \%$ & 8,03 \\
\hline 2014 & 5473,8 & 1595,20 & 7069,00 & 635 & 234 & 869 & 8,62 & $-0,57 \%$ & 6,82 & $6,63 \%$ & 8,13 \\
\hline 2015 & 5623,7 & 1381,90 & 7005,60 & 653 & 204 & 857 & 8,61 & $-0,09 \%$ & 6,77 & $-0,63 \%$ & 8,17 \\
\hline & & & & & & & & $-2,31 \%$ & & $-1,80 \%$ & \\
\hline
\end{tabular}

Sources: American Association of Publisdhers (AAP) - Monthly Statshot
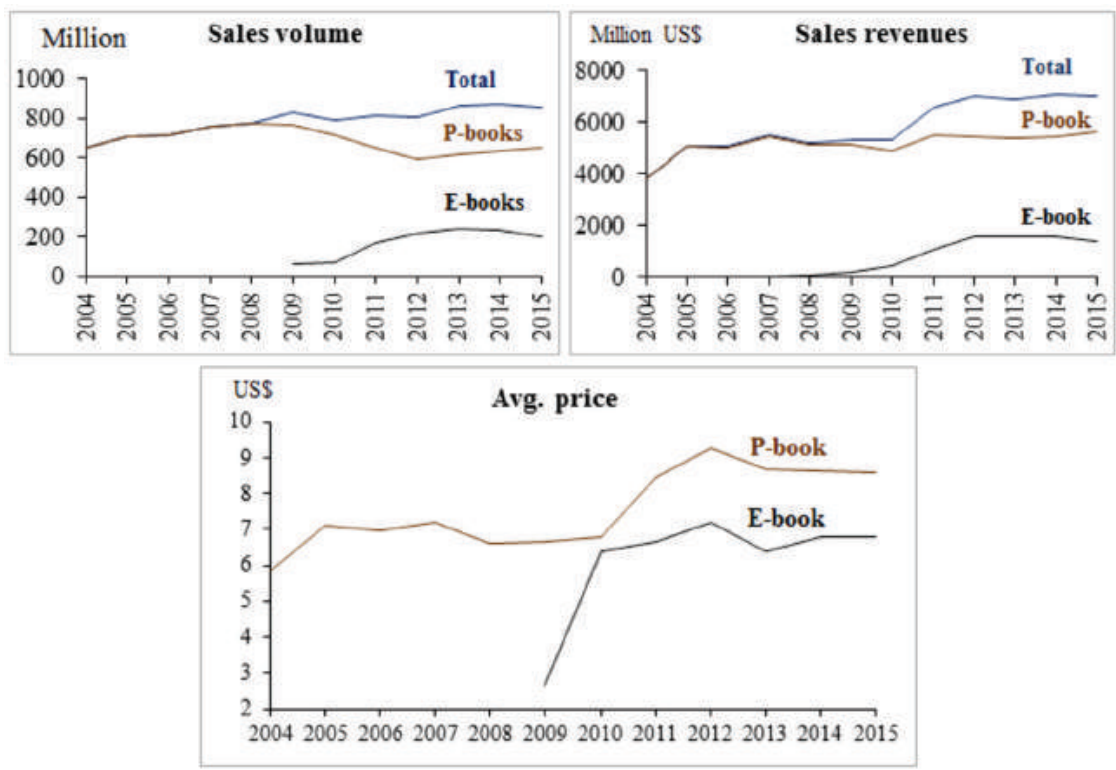

Figure 9: Trends in Sales Volume, Sales Revenues and Prices of Books in the US by Types (2004-2015).

Sources: Nielsen BookScan US/Pub Track digital US

Looking at Table 1 and Fig. 9 we note that book sales both by volume and revenues have been sustained by the e-books popularized in 2008 and substituted for traditional print (physical) books (p-books). However, this

Journal of Technology Management for Growing Economies, Volume 8, Number 2, October 2017 
substitution changed from 2012. Contrary to re-gaining popularity of p-books, sales volume and subsequent sales revenues increase in e-books have stagnated. This "renaissance" of p-books remind us of the resurgence of the US music industry initiated by the "renaissance" of live music by assimilating digital innovation initiated by digital music (Naveed et al., 2017).

Inspired by this noting "renaissance" in p-books, Fig. 10 reviews trends in sales volume of p-books and e-books in the US over the period of 2004-2015.

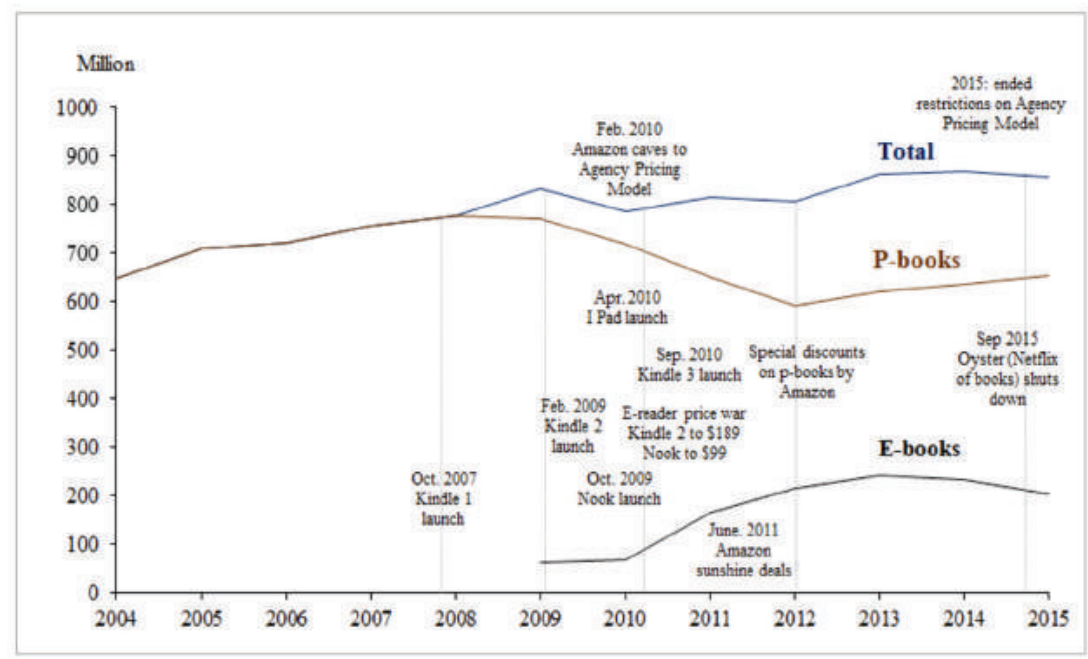

Figure 10: Trends in Print-Book and Electronic-Book Volume in the US (2004-2015).
Transformation of the Forestbased

Source: Nielsen BookScan US/PubTrack Digital US.

Fig. 10 demonstrates "renaissance" of p-book and contrasting fading popularity of e-books emerged from 2012. Noteworthy is that these trends proceeded together with advancement of digitally-rich environments and activation of e-commerce giant Amazon against active digital solution challenge.

In order to further analyze dynamism leading to "renaissance" of p-book under digitally-rich environments and Amazon's digital solution challenge, Fig. 11 compares dynamism between price decrease and sales volume increase in p-books and e-books.

Fig. 11 demonstrates that contrary to e-books behavior, p-books constructed a virtuous cycle between price decrease and sales volume increase after 2012 while they suffered a vicious cycle previously. This dynamism may be the source of p-books "renaissance" and this can largely be attributed to Amazon's digital solution oriented strategy (Johnson et al., 2017).

Prices Decrease Rate of Books in the US by Types (average in 2013-2015). 
Watanabe, $\mathrm{C}$.

Naveed, N.

Naveed, K.

Neittaanmäki, P.
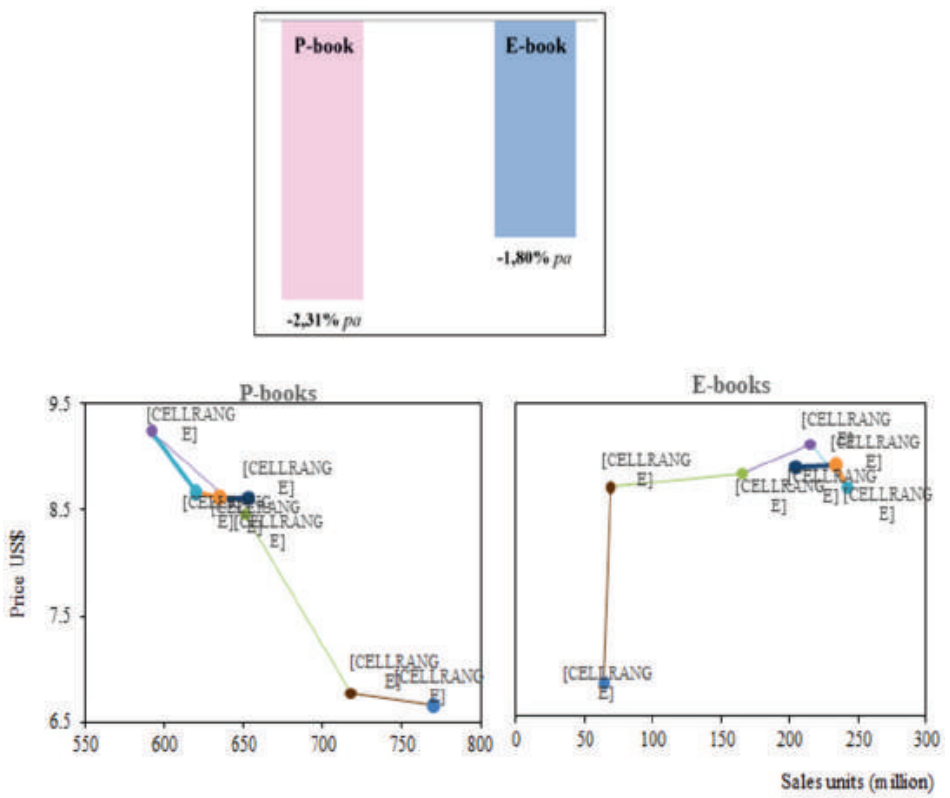

Correlation between Prices and Sales Volume of P-book and E-book in the US (2009-2015).

Figure 11: Dynamism between Price Decrease and Sales Volume Increase in P-books and E-books

Source: Authors calculated the prices on the basis of sales volume and sales revenues of P-books and E-books from Nielsen BookScan US/Pub Track digital US and AAP - Monthly Statshot

\section{Customer's Buying Behavior}

Amazon pays special attention to customers propensity that "We read our news on tablets and phones, work all day on screens, but at the end of the day we might just want something on paper - a book, magazine, or newspaper - to read with thought and relax" (Stora Enso, 2017)

Given that p-books "renaissance" can largely be attributed to Amazon's digital solution oriented strategy, however customers' buying behavior should be analyzed.

With this postulate in mind, Fig. 12 analyzes customers' buying behavior of books in the US. Figure 12 demonstrates continuous increase in e-commerce in buying books in the US (Fig. 12-1), Fig. 12-2 demonstrates noteworthy change that books sale by bookstores changed to increase in 2016, first time after decline from 2007.

This change demonstrates one of the institutional source of p-books "renaissance" similar to that of live music in the US music industry (Naveed et al., 2017). People preference shift from excessive e-books and e-commerce to p-books by brick and mortal shopping should not be overlooked. Taking such 
trend, Amazon opened its first brick and mortar bookstore in 2015 and it is planning to open 300-400 new bookstores (Lavecchia, et al., 2016).

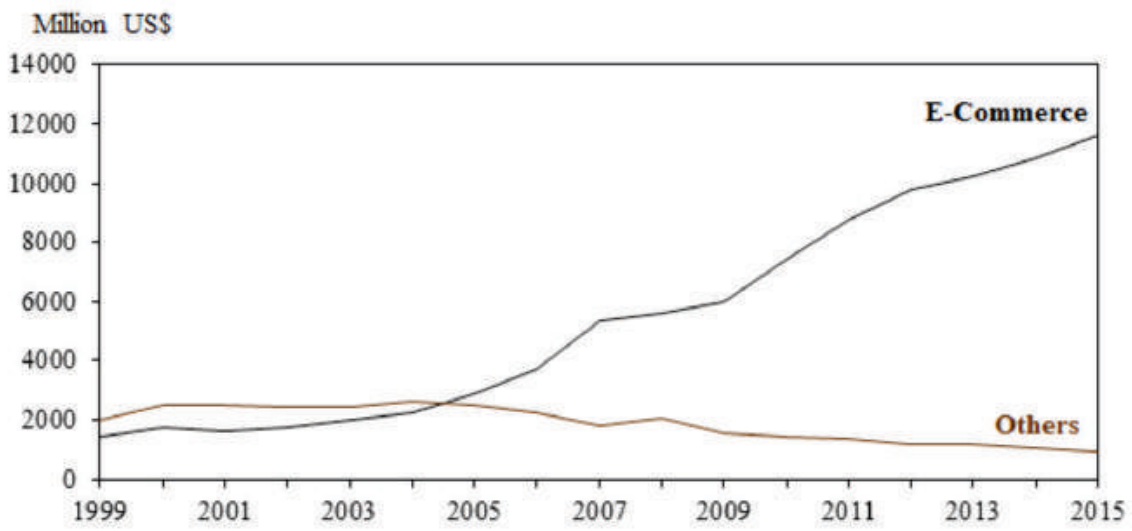

Figure 12-1: Trends in Books Sale in the US by Buying Behavior (1999-2015).

Source: United States Census Bureau.

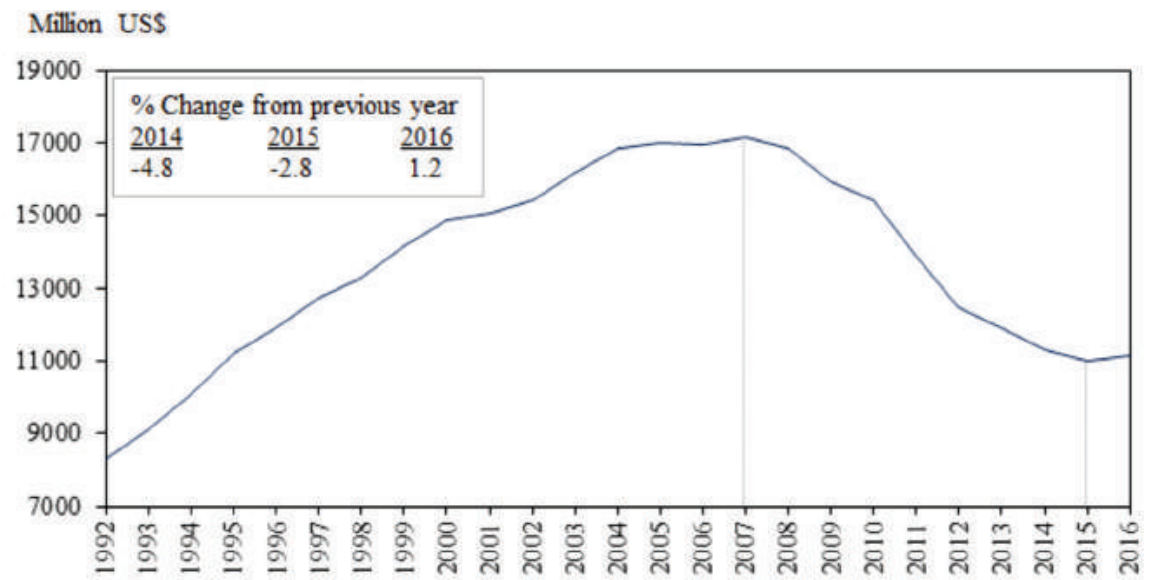

Figure 12-2: Trends in Books Sale by Bookstores in US (1992-2016).

Source: United States Census Bureau

Figure 12: Changing Trends in Customers' Books Buying Behavior in the US

\section{Amazon's Disruptive Business Strategy}

As reviewed earlier, Amazon's digital oriented strategy has provided significant impact on p-books "renaissance" in the US. With its basic principle of "merging

Journal of Technology Management for Growing Economies, Volume 8, Number 2, October 2017 
Watanabe, $\mathrm{C}$. Naveed, N. Naveed, K. Neittaanmäki, P.

net and real" Amazon has been endeavoring ICT-driven disruptive business strategy. In line with this strategy, Amazon acquired a giant physical store, Whole Foods in June 2017 (Yglesias, 2017). Opening a considering number of brick and mortar bookstores is in line with this strategy

The new business strategy of Amazon is driven by a company's reaction time to changes in consumer demand and preferences. Each transaction tailors the experience for both the retailers and customers. From the operational perspective, inventory inefficiencies are virtually eliminated and from customer's perspective, there is never-ending supply of inventory. Table 2 summarizes this strategy.

Table 2 Amazon's Disruptive Business Strategy

\begin{tabular}{|c|c|c|}
\hline \multicolumn{3}{|c|}{ Amazon Business Strategy (It's all about customers) } \\
\hline & Action & Impact \\
\hline Eliminate & $\begin{array}{l}\text { Traditional retail distribu- } \\
\text { tion channel } \\
\text { Manual billing and } \\
\text { shipping }\end{array}$ & $\begin{array}{l}\text { - } \quad \text { Direct relationship with customers } \\
\text { - Accelerated transaction time }\end{array}$ \\
\hline Raise & $\begin{array}{ll}\text { - } & \text { Online shopping platform } \\
\text { - } & \text { Products range } \\
\text { - } & \text { Customer shopping } \\
& \text { experience } \\
\text { - } & \text { Quality of service } \\
\text { - } & \text { Product comparisons }\end{array}$ & $\begin{array}{l}\text { Reinvented the traditional retail business } \\
\text { model and fundamental dynamics of } \\
\text { how consumers shop } \\
\text { Gives customers unprecedented choice, } \\
\text { scope and value }\end{array}$ \\
\hline Create & $\begin{array}{l}\text { - Amazon Web Service } \\
\text { (AWS) offering } \\
\text { - } \quad \text { Features like " } 1-\text { Click } \\
\text { checkout" } \\
\text { - } \begin{array}{l}\text { Product recommendations } \\
\text { system }\end{array}\end{array}$ & $\begin{array}{l}\text { - Makes web-scale cloud computing } \\
\text { cheaper and more accessible } \\
\text { - First-mover advantage and high compa- } \\
\text { ny growth }\end{array}$ \\
\hline Reduce & $\begin{array}{ll}- & \text { Product prices } \\
- & \text { Short-term profitability }\end{array}$ & $\begin{array}{l}\text { - Massive market share and scale } \\
\text { - } \\
\text { ity in future } \\
\text { - High emotional switching costs for } \\
\text { customers } \\
\text { - Extremely high barriers for competitors } \\
\text { in the future }\end{array}$ \\
\hline \multicolumn{3}{|c|}{$\begin{array}{c}\text { Acquisition of a giant physical store, Whole Foods - merging net and real } \\
\text { (cf. Co-evolution of live music and streaming music) }\end{array}$} \\
\hline \multicolumn{3}{|c|}{$\begin{array}{l}\text { Original source: Johnson et al. (2017). American Association of Publisdhers (AAP) - Monthly } \\
\text { Statshot }\end{array}$} \\
\hline \multicolumn{3}{|c|}{$\begin{array}{l}\text { Given the significant role that Amazon plays in the very end of the downstream of pulp } \\
\text { and paper industry chain, its digital oriented strategy, ICT-driven disruptive business } \\
\text { strategy will impacts on the upstream of this forest-based bioeconomy chain. }\end{array}$} \\
\hline
\end{tabular}

Journal of Technology Management for Growing Economies, Volume 8, Number 2, October 2017 


\section{STRUCTURAL CHANGE IN UPSTREAM}

\section{A Fluid Industry Ecosystem}

Inspired by the foregoing resurgent possibility in pulp and paper industry observed in the downstream of its value chain, particularly in the US p-books market, structural change in upstream of the chain was analyzed focusing on its leader, Finland.

Fig. 13 demonstrates trend in paper and paperboard export from Finland over the period 1960-2016. This Figure illustrates that sharp decline of Finland's export from the Lehman shock in 2008 changed to slight upturn from 2015. While we should watch carefully the following trend, Finnish forest industries federation stands on the positive prospect with respect to the nation's export on the industry as the industry has been transforming by embracing digital solutions (PTT, 2016).

A possible sign of resurgence in the downstream market as observed in the p-books market in the US provides confidence of its prospect. Furthermore, transformation trend in the whole value chain of pulp and paper industry toward digital solutions and Amazon's ICT-driven disruptive business strategy as reviewed in the preceding sub-section suggests a possibility of creative disruption platform embracing digital solutions through the whole value chain of this industry.

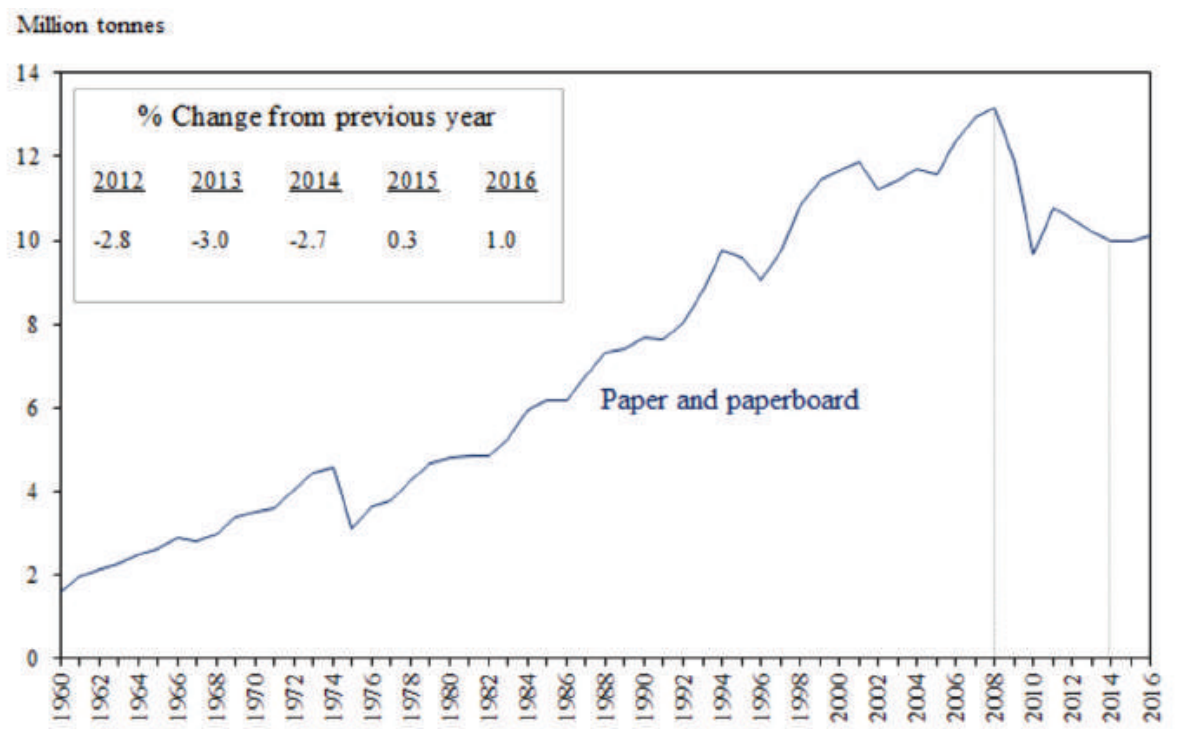

Figure 13. Trend in Paper and Paperboard Export from Finland (1960-2016).

Source: Finnish Forest Industries (2016).
Transformation of the Forestbased 


\section{Watanabe, C. Embracing Digital Solution for Competitiveness}

Naveed, $\mathrm{N}$.

Naveed, K.

Neittaanmäki, P.

Corresponding to the foregoing anticipation toward digital solutions noteworthy digital solutions challenge can be observed in leading forest firms in Finland.

Table 3 demonstrates noteworthy digital solutions challenge initiated by leading forest firms in Finland such as UPM, Stora Enso and Metsä. By utilizing advanced digital innovation such as digital maps, GPS, online wood trade, drone helicopters and virtual reality these leading firms have been endeavoring to replacing the traditional non-renewable materials with renewable, recyclable and low-impact alternatives.

Table 3: Noteworthy Digital Solutions Challenge in Leading Forest Firms in Finland

\begin{tabular}{|l|l|}
\hline \multicolumn{2}{|l|}{$\begin{array}{l}\text { Digital maps, GPS, Online wood trade, Drone helicopters for forest inventory, } \\
\text { Virtual reality }\end{array}$} \\
\hline UPM & $\begin{array}{l}\text { Versatile use of renewable wood biomass, combined with inno- } \\
\text { vation, resource efficiency and sustainability aiming at replacing } \\
\text { non-renewable materials with renewable and low-impact alternatives }\end{array}$ \\
\hline Stora Enso & $\begin{array}{l}\text { Transforming from a traditional paper and board producer to a } \\
\text { renewable materials growth company by means of a strong customer } \\
\text { focus and new innovation approaches }\end{array}$ \\
\hline Metsa & $\begin{array}{l}\text { Asset management to be accessible of time or place, thereby making } \\
\text { forest management easier. Resource efficiency, vast potential of } \\
\text { renewable raw materials and value of products }\end{array}$ \\
\hline
\end{tabular}

Sources: UPM (2017), Stora Enso (2017), Metsä (2017).

\section{UPM's Disruptive Business Strategy}

UPM has changed its business model from a vertically integrated forest industry model into a company with six separate business areas. UPM has a versatile business portfolio and good geographic spread. The versatile use of forest biomass and focus on competitiveness and innovation will continue to advance their Biofore strategy.

UPM's Biofore strategy includes continuous improvement programmes and short-term actions to drive performance; mid-term growth projects as well as mid- to long-term development work to create new, high value-added growth (UPM Annual Report, 2016).

With such endeavor supported by the advancement of digital innovation, ICT-driven disruptive business strategy, similar to leading challenge observed in the downstream of the value chain initiated by Amazon, has been undertaken by leading firms in the upstream of the chain.

Table 4 demonstrates leading endeavor initiated by UPM. Its eco- 
design approach consists of 8 steps as (i) selection of low impact materials, (ii) reduction of material usage, (iii) optimization of production techniques, (iv) optimization of distribution systems, (v) reduction of impact during use, (vi) optimization of initial lifetime, (vii) optimization of end-of-life system, and (viii) new concept development. Advanced innovation has been deeply involved in each respective steps and systems integration has been accelerated thereby effects of digital solution can be maximized.

Table 4: UPM's Eco-design Approach
Transformation of the Forestbased

\begin{tabular}{|c|l|}
\hline $\begin{array}{c}\text { 1. Selection of low } \\
\text { impact materials }\end{array}$ & $\begin{array}{l}\text { Selection of low-impact materials, for example, by replacing } \\
\text { fossil fuels with bioenergy and fossil raw materials with sus- } \\
\text { tainable options. }\end{array}$ \\
\hline $\begin{array}{c}\text { 2. Reduction of ma- } \\
\text { terial usage }\end{array}$ & $\begin{array}{l}\text { Reduction of material usage by applying smart production } \\
\text { techniques, designing longer-lasting products with less material } \\
\text { and reusing components. }\end{array}$ \\
\hline $\begin{array}{c}\text { 3. Optimization of } \\
\text { production tech- } \\
\text { niques }\end{array}$ & $\begin{array}{l}\text { Optimization of product techniques by continuously improving } \\
\text { operational performance, for example, by reducing energy and } \\
\text { water consumption and by sharing services and utilities. }\end{array}$ \\
\hline $\begin{array}{c}\text { 4. Optimization } \\
\text { of distribution } \\
\text { systems }\end{array}$ & $\begin{array}{l}\text { Optimization of distribution systems, for example, by using } \\
\text { lighter and reusable packaging in end-product delivery. }\end{array}$ \\
\hline $\begin{array}{c}\text { 5. Reduction of im- } \\
\text { pact during use }\end{array}$ & $\begin{array}{l}\text { Reduction of impact during use by lowering the environmental } \\
\text { impact of customer processes, for example, by offering lighter } \\
\text { paper grades to reduce the fuel consumption of distribution. }\end{array}$ \\
\hline $\begin{array}{c}\text { 6. Optimization of } \\
\text { initial lifetime }\end{array}$ & $\begin{array}{l}\text { Optimization of initial lifetime by offering extended-life prod- } \\
\text { ucts that are multifunctional and recyclable, easy to maintain } \\
\text { and repair. }\end{array}$ \\
\hline $\begin{array}{c}\text { 7. Optimization of } \\
\text { end-of-life system }\end{array}$ & $\begin{array}{l}\text { Optimization of end-of-life systems by selecting non-toxic, } \\
\text { reusable materials that are easily separated and sorted for reuse. }\end{array}$ \\
\hline development & $\begin{array}{l}\text { New concept development, for example, thinking of new ways to use } \\
\text { the product already in the design phase, without forgetting multi-func- } \\
\text { tionality and shared use. }\end{array}$ \\
\hline
\end{tabular}

Source: Ecodesigned Products (UPM, 2017).

In UPM, transformation of business strategy, business portfolio and business performance started back in 2008. UPM has yielded the following benefits in recent years through the appreciation of above eco-design approach:

1) Transparency and accountability - commercial strategies, benchmarking, 
Watanabe, $\mathrm{C}$. Naveed, N. Naveed, K. Neittaanmäki, P. target setting, incentives.

2) Cost competitiveness - agility, improved efficiency, optimized sourcing.

3) Growth - focused investments with attractive returns and clear competitive advantage.

UPM aims to add value to its business with competitive and responsible operations through building a global platform.

\section{Creative Disruption Strategy}

Appreciated by accelerating endeavor towards digital solutions initiated in the forefront of downstream and upstream of the value chain of pulp and paper industry as reviewed in the preceding section, creative disruption platform embracing digital solutions can be anticipated. Fig. 14 illustrates the concept of this platform.

Advancement of digital innovation leverages reconstruction of traditional institutional systems indigenous to conventional forest-blinded economy encompassing (i) low productive production system, (ii) rigid rules and conventional customs, (iii) traditional business models, and (iv) law and regulations applicable to non-digital economies.

Reconstructed institutional systems in turn create new business systems such as (i) new digital technologies, (ii) products and services, and (iii) new business model.

These new business systems accelerate reconstruction of traditional institutional systems. Thus mutually inspiring virtuous cycle between disruption and creation emerges leading to constructing creative disruption platform embracing digital solutions.

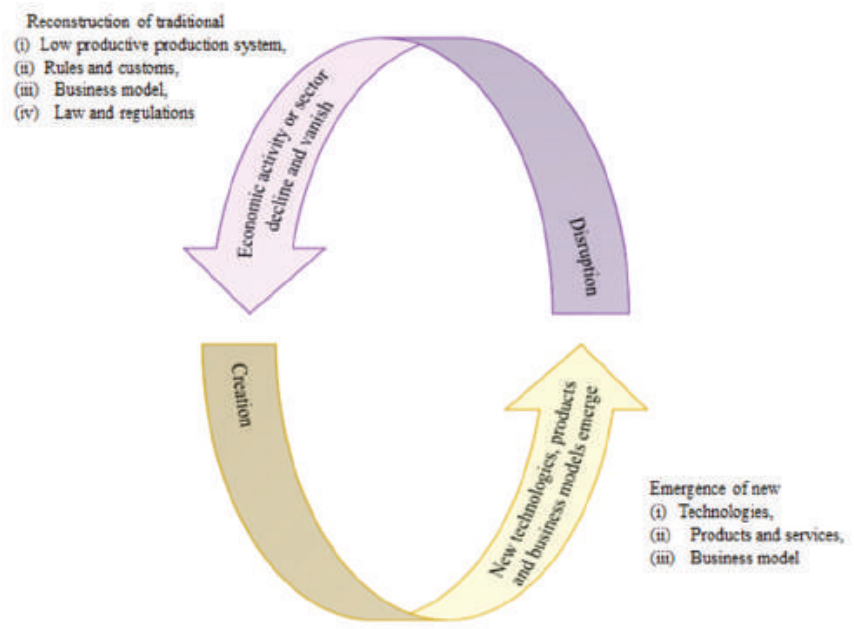

Figure 14: Creative Disruption Platform Embracing Digital Solutions Source: Authors'elaboration based on Heitemaki, 2016

Journal of Technology Management for Growing Economies, Volume 8, Number 2, October 2017 


\section{Digital Solutions in Transformation into Creative Disruption Platform}

Advancement of digital innovation thus transforms value chains of forest industry into creative disruption platform in a stepwise way as illustrated in Fig. 15.

Traditional one way supply chain from forestry to consumption (step 1) transforms into creative disruption platforms within upstream and downstream, respectively (step 2). Further digital solutions in downstream leverage disruption of upstream (step 3) which reacts to inducing new business systems creation in downstream (step 4). Thus creative disruption platform through whole value chain of the forest-based bioeconomy can be expected.
Transformation of the Forestbased

\section{Upstream}

1.

One Way Supply Chain

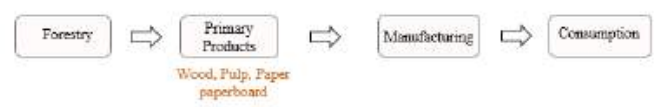

2 .

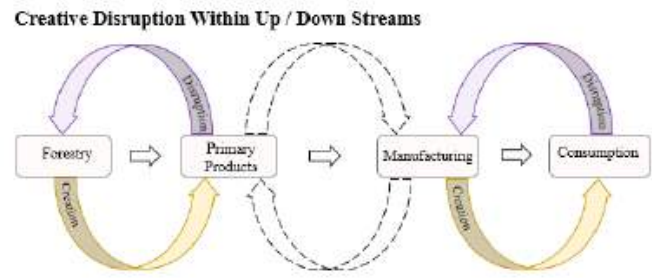

3.

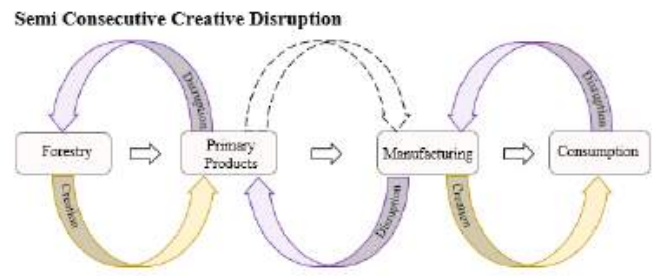

4. Consecutive Creation Disruption

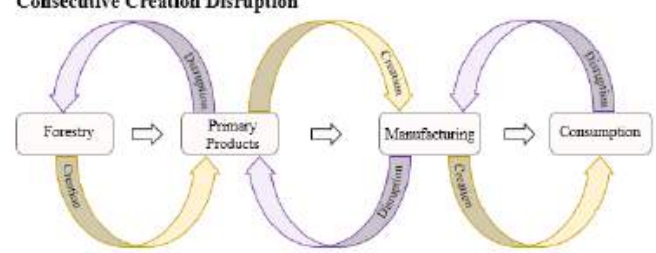

Figure 15: Steps in Constructing Creative Disruption Platform by Embracing Digital Solutions

Source: Authors'elaboration based on (Beamon, 1998) and (Hetemaki, 2016). 
Watanabe, $\mathrm{C}$. Naveed, N. Naveed, K. Neittaanmäki, P.

\section{Analysis of Creative Disruption Platform Construction}

In order to demonstrate the foregoing hypothetical expectation with respect to possible transformation of forest-based bioeconomy into creative disruption platform, an empirical analysis was conducted focusing on the effects of creative disruption in downstream on upstream market.

Fig. 16 outlines framework of this analysis. Aiming at demonstrating the emergence of the above creative disruption, the analysis was focused on the effects of Amazon's creative disruption efforts in downstream as reviewed in 2.2 on market capitalization of UPM, leading firm in upstream as reviewed in 2.3 (See the details of yearly statistics Appendix 1).

External stimulation

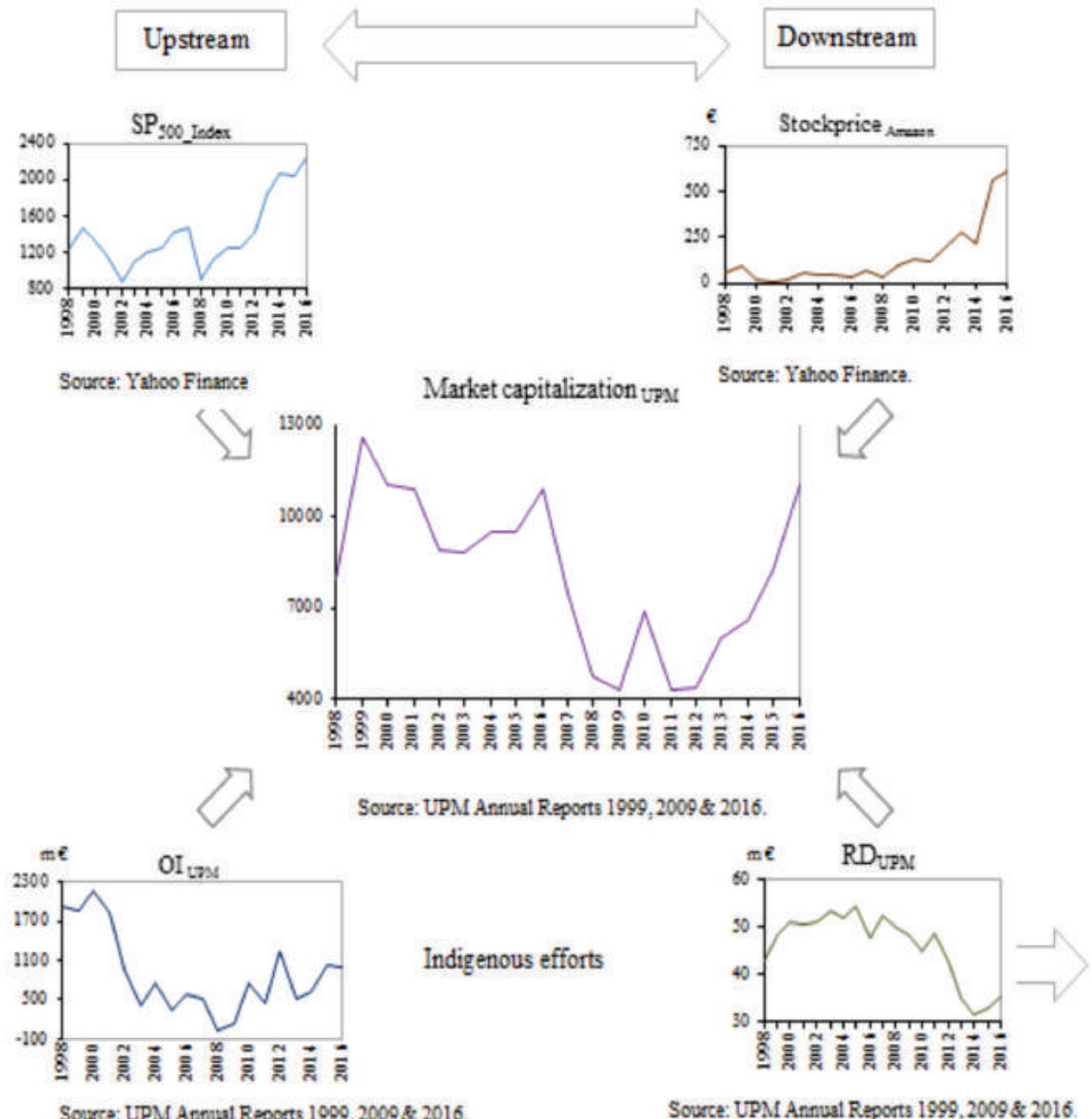

Figure 16: Effects of Creative Disruption in Downstream on the Market Value Increase in Upstream Firm - A Case of UPM (1998-2016). 
It is generally postulated that market capitalization of UPM is governed by its indigenous efforts as operating income improvement and increase in R\&D investment increase. It is also subject to external situations as economic environment represented by S\&P 500 index in the EU. Furthermore, given the creative disruption between upstream and downstream, it should be influenced by Amazon's creative disruption efforts in downstream as represented by its stock price.

Based on postulate, a correlation analysis identifying the governing factors of market value of UPM was conducted. Table 5 summarizes the result of the correlation analysis between market value of UPM and governing factors to this value both in upstream and downstream over the period 1998-2016.

Table 5: Correlations between Market Value of UPM and Governing Factors both in Upstream and Downstream (1998-2016)

adj. $R^{2} 0.933$

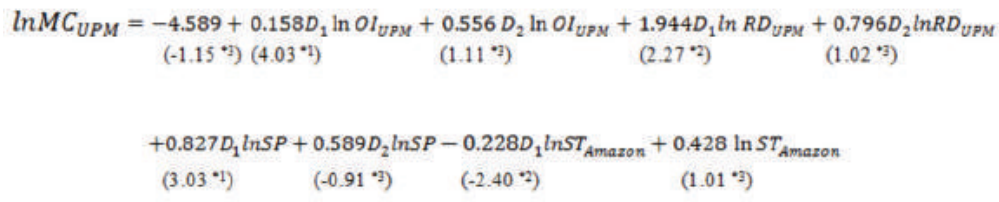

$M C$ : Market capitalization, $O I$ : Operating income, $S T$ : Stock price, $R D$ : R\&D investment

$S P: S \& P 500$ index (closing price Dec.)

$D_{1} D_{2}$ are dummy variables.

$D_{1}:(2000-2011)=1$, others $=0 ; D_{2}:(2012-2016)=1$, others $=0$;

The figures in parenthesis indicate t-statistics: Significant at the ${ }^{{ }_{1}} 1 \%,{ }^{{ }_{2}} 5 \%$ and ${ }^{*_{3}}$ $30 \%$ level.

Table 5 demonstrates that market value of UPM is subject to indigenous efforts as operating income improvement and R\&D increase as well as economic environment as generally anticipated. In addition, Table 5 demonstrates the significant effect of stock price of Amazon that represents the consequence of creative disruption efforts in downstream. While this effect reacted negative impact on UPM market value up until 2011, it changed to positive inducement from 2012 corresponding to Amazon's creative disruption efforts endeavored from these years as reviewed in 2.2. This positive reaction could be considered as an evidence of the emergence of creative disruption between downstream and upstream of the value chain.

Fig. 17 demonstrates correlation between stock prices of Amazon and UPM and supports the forgoing correlation analysis. Fig. 17 demonstrates that Amazon's stock price increase induced UPM's stock price from 2013.

Journal of Technology Management for Growing Economies, Volume 8, Number 2, October 2017 
Watanabe, C.

Naveed, N.

Naveed, K.

Neittaanmäki, P.

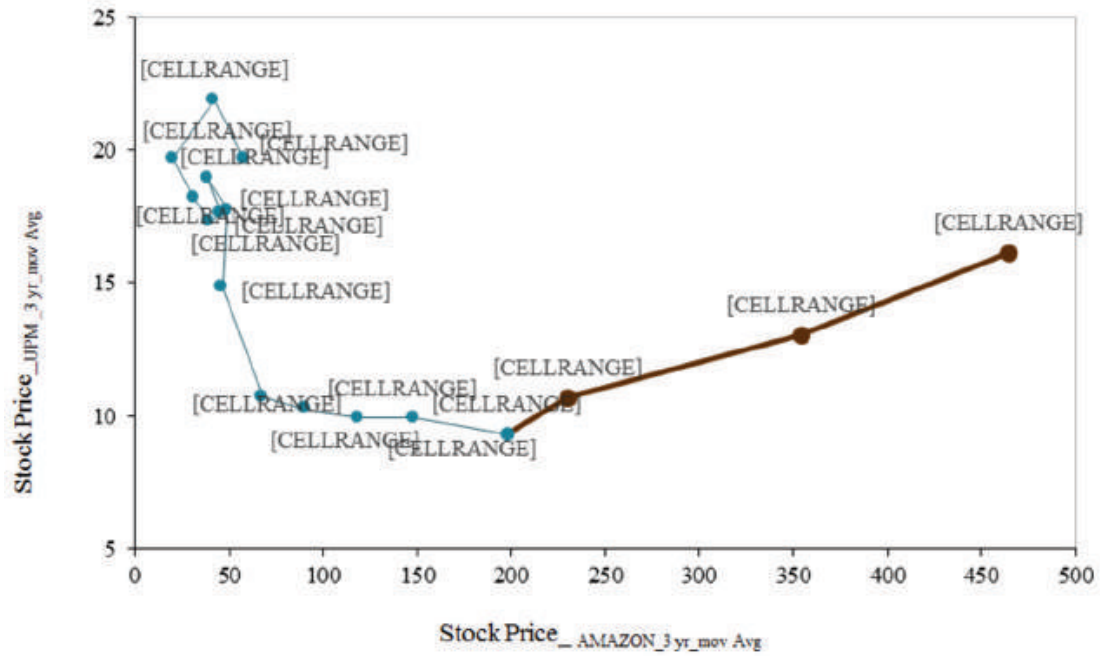

Figure 17: Correlation between Stock prices of Amazon and UPM (2000 - 2016).

3 -years moving average

Source: Yahoo Finance and Nasdaq Helsinki Stock Exchange

On the basis of the foregoing analyses consecutive creative disruption between Amazon and UPM as illustrated in Fig. 18 was demonstrated. This suggests digital solutions in transformation into creative disruption platform in the forest-based bioeconomy.

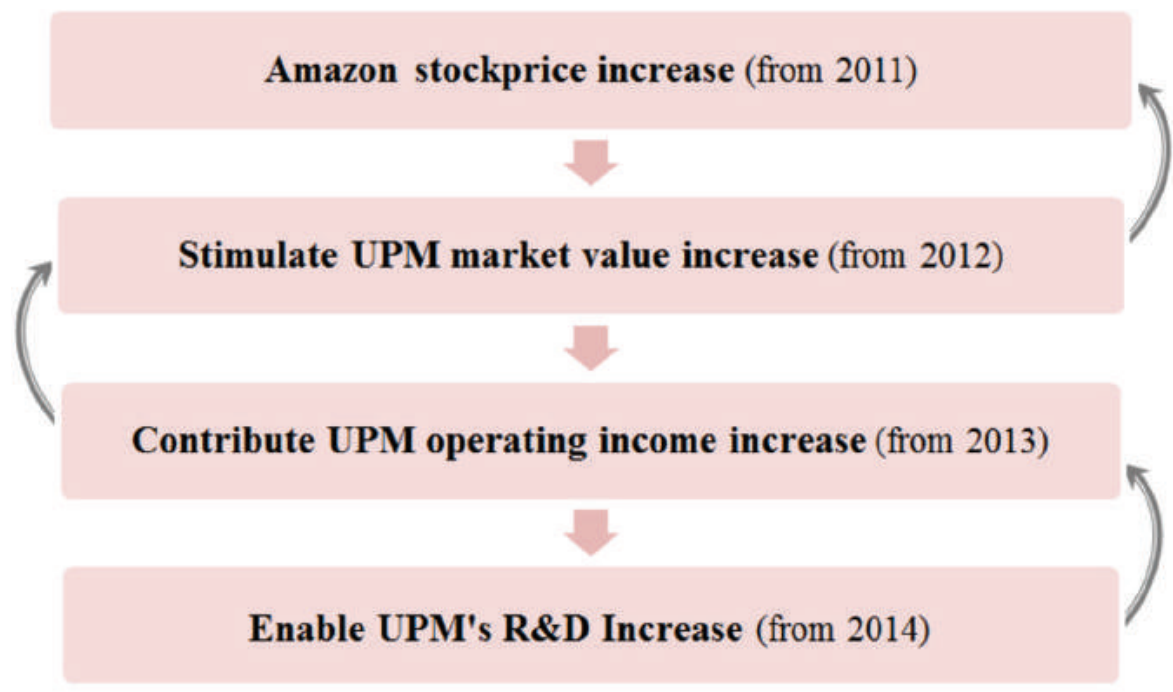

Figure 18: Consecutive Creative Disruption between Amazon and UPM 


\section{CONCLUSION}

In light of the noteworthy transformation stream observed in the forefront of forest-based bioeconomy by embracing digital solutions, its platform dynamism was analyzed. An empirical analysis focusing on the noteworthy forefront business activities in both upstream and downstream of the supply chain was conducted. UPM (Finland's leader) and Amazon (US leader) were taken as representing respective stream. Noteworthy findings include:

(i) Similar to music industry, resurgent trend can be observed in recent years in book industry.

(ii) This is initiated by a renaissance of p-books.

(iii) This renaissance can be attributed to people preference shift from excessive e-books to p-books and also e-commerce to brick and mortal shopping.

(iv) Digital innovation enabled to satisfy this requirement by constructing a virtuous cycle between price decrease and purchase increase in p-books.

(v) Correspond to such transformation stream in print media industries, e-commerce giant Amazon has endeavored creative disruption by merging net and real through acquiring giant physical stores.

(vi) Induced by such a significant transformation stream in the forefront of downstream of forest-based bioeconomy, similar ICT-driven transformation stream has impacted on the upstream of the economy.

(vii)Forest and its products industries have also been transforming by embracing digital solutions.

(viii)This transformation, in turn further accelerates the transformation of downstream of the economy.

(ix) Thus, creative disruption platform has taken big steps in the whole chain of forest-based bioeconomy.

(x) All can be attributed to the digital innovation that enables real-time endto-end supply chain visibility, improved delivery accuracy, stock level optimization and alignment with demand planning.

These findings give rise to the following insightful suggestions to industries confronting the transformation stream:

(i) Given that the largest share of production and consumption of forest-based bioeconomy depends on Asia, US-Europe initiated digital solutions-oriented transformation should be transferred to growing economies centered by Asia.

(ii) Through such transferring efforts, this transformation should trigger worldwide collaboration between industrialized and growing economies.

(iii) In addition, this endeavor should be a prototype of construction of creative
Transformation of the Forestbased 
Watanabe, $\mathrm{C}$. Naveed, N. Naveed, K. Neittaanmäki, P.

disruption platform cross over industries.

(iv) Similar platform should be considered in such fields in strong social demand as healthcare, education and transportation.

(v) Co-evolution between transformation of business model and further advancement of digital solutions should be accelerated.

(vi) To thrive in digital era, sometimes it's better to execute the existing business model well like Amazon than to re-invent the business model from scratch.

This research thus explores a new insight common to both industrialized and growing economies in constructing creative disruption platform by embracing digital solutions.

However, due to constraints of reliable data on the very latest business activities, successive careful monitoring should be strongly recommended.

Further work should focus on complementing these constraints and unexplored analysis as well as in-depth analysis of success and failure trajectories with respect to creative disruptive platform. Moreover, exploration of the possibilities of how digitalization and digital platforms may improve the competitiveness and profitability of forest-based industries through better productivity, cost reductions, better market understanding and by improving transparency across the value chain in order to capitalize the global business opportunities should be taken priority basis.

\section{FOOTNOTE}

1. World pulp and paper industry leaders and their digital ability (2015)

Production (Wood pulp) Export (Paper and paperboard) Consumption

1. USA

2. Canada (11)

3. Brazil (84)

4. Sweden (3)

5. Finland

1. Germany (13)

2. USA

3. Finland

4. Sweden

5. Canada

(Paper and paperboard)

1. China

2. USA

3. Japan

4. Germany (13)

5. India

2. Sales revenues data does not include professional publishing, K-12 instructional material and higher education course materials.

3. Paper include printing, writing, newspaper and other paper.

\section{REFERENCES}

American Association of Publishers (AAP), 2016. Monthly Statshot. AAP, New York.

Beamon, B., (1998) "Supply chain design and analysis: Models and methods", International Journal of Production Economics. 55(3), 281-294. https://dx.doi.org/10.1016/S09255273(98)00079-6.

CEPI (Confederation of European Paper Industries), 2014. Key Statistics 2014: European Pulp

Journal of Technology Management for Growing Economies, Volume 8, Number 2, October 2017 
\& Paper Industry. CEPI, Brussels.

CEPI (Confederation of European Paper Industries), 2015. What Digital Can Do for the Paper Industry. CEPI, Brussels.

CEPI (Confederation of European Paper Industries), 2017. Key Statistics 2016: European Pulp $\&$ Paper Industry. CEPI, Brussels.

Finnish Forest Industries, 2016. Statistics, https://www.forestindustries.fi/statistics/industry/ Retrieved 2 March. 2017.

Food and Agriculture Organization (FAO), 2016. Statistics, United Nations. Rome.

Giurca, A., Späth, P., (2017) "A forest-based bioeconomy for Germany? Strengths, weaknesses and policy options for lignocellulosic biorefineries", Journal of Cleaner Production 153, 51-62. https://dx.doi.org/10.1016/j.jclepro.2017.03.156.

Hetemaki, L., (2016) Role of Sustainable Forest-based Bioeconomy in Europe. Think Forest, 15 November 2016, Brussels.

Hetemaki, L., Hoen, H.F. and Schwarzbauer, P., (2014) Future of the European Forest-based Sector and Bioeconomy, in Hetemaki, L. edt., Future of the European Forest-based Sector: Structural Changes towards Bioeconomy. European Forest Institute, Joensuu.

Johnson, N., Miller, O. and Moffitt, D. (2017) Disruption at the Gates: Monitoring the Threat of Amazon Business. 2017 Applico, February 2017, 1-18.

Lavecchia, O., Mitchell, S. (2016) How the company's tightening grip is stifling competition, eroding jobs, and threatening communities, Institute for Local Self-Reliance, Washington DC.

Mubareka, S., Jonsson, R., Rinaldi, F., Azevedo, J. C., de Rigo, D., Sikkema, R. (2016) Forest bio-based economy in Europe. (Eds.) European Atlas of Forest Tree Species. Publ. Off. EU, Luxembourg.

Mustalahti, I. (2017) The Responsive Bioeconomy: The Need for Inclusion of Citizens and Environmental Capacity in the Forest-based Bioeconomy", Journal of Cleaner Production, in print. https://dx.doi.org/10.1016/j.jclepro.2017.06.132.

Naveed, K., Watanabe, C., and Neittaanmäki, P. (2017) Co-evolution between Streaming and Live Music Leads a Way to the Sustainable Growth of Music Industry - Lessons from the US Experiences. Technology in Society, 50, 1-19. https://dx.doi.org/10.1016/j.techsoc.2017.03.005.

Nebe, S. (2011) Bio-based economy in Europe: State of play and future potential - Part 2 Summary of position papers received in response to the European Commission's Public online Consultation. Public Office of the European Union, Luxembourg.

Nielsen, (2016) Nielsen BookScan /Pub Track Digital US. Nielsen, New York.

Pelli, P., Haapala, A. and Pykalainen, J. (2017) Services in the Forest-based Bioeconomy: Analysis of European Strategies. Scandinavian Journal of Forest Research, online 17 Feb March 2017.2017. http://dx.doi.org/10.1080/02827581.2017.1288826.

Poyry, (2017) The Pulp and Paper Industry in Finland, Poyry, Vantaa, Finland.

PTT, (2016) Finland's Forest and Paper Industry Continues Structural Change. Paper Age.

http://www.paperage.com/2016news/10_19_2016finland_pulp_paper_forecast.htmlRetrieved2 March 2017.

Scarlat, N., Dallemand, J., Monforti-Ferrario, F., Nita, V. (2015) The role of biomass and bioenergy in a future bioeconomy: policies and facts. Journal of Environmental Development. 15, 3-34. https://dx.doi.org/10.1016/j.envdev.2015.03.006.

Stora Enso, (2017) A Focused Strategy. Stora Enso,

Tieto, (2017) Introducing Forest Hub: Digitalizing Wood and Fiber Supply. Tieto Corporation, Espoo

The Institute for Sustainable Development and International Relations (IDDRI) (2017) Developing Decarbonization Strategies in the EU: Insights on Good Practice from National Experiences. IDDRI, Paris.
Transformation

of the Forest-

based 
Watanabe, $\mathrm{C}$. Naveed, N.

Naveed, K.

Neittaanmäki, P.
Topinen, A., Patari, S., Tuppura, A., Jantunen, A. (2017) The European pulp and paper industry in transition to a bio-economy: A Delphi study. The journal of policy, planning and futures studies 88, 1-14. https://dxdoi.org/10.1016/j.futures.2017.02.002.

UPM, (1999) Annual Report. http://web.lib.hse.fi/FI/yrityspalvelin/pdf/1999/Eupmkymmene1999.pdf Retrieved 30 June 2017.

UPM, (2009) Annual Report. http://assets.upm.com/Investors/Documents/2009/Annual_Report_2009_UPM_VSK_EN.pdf Retrieved 30 June 2017.

UPM, (2016) ${ }^{-}$Aiming Higher with Biofore: Annual Report 2016. http://hugin.info/165629/R/2081401/784910.pdf Retrieved 30 June 2017.

UPM, Ecodesigned Products,

http://www.upm.com/Responsibility/Product-stewardship/ecodesigned-products/Pages/default. aspx

Retrieved 2 August 2017.

Nasdaq Helsinki Stock Exchange, UPM Stock Prices. http://www.nasdaqomxnordic.com/aktier/microsite? Instrument=HEX24386 Retrieved 28 July 2017.

United States Census Bureau, (2017) Data: Bookstores. https://www.census.gov/data.html

Retrieved 23 June 2017.

Watanabe, C., Naveed, K. and Neittaanmäki, P., (2016) Co-evolution of Three Mega-trends Natures Un-captured GDP: Uber's Ride-sharing Revolution. Technology in Society, 46, 164-185.

Watanabe, C., Naveed, K. and Neittaanmäki, P., (2017a). Consolidated Challenge to Social Demand for Resilient Platforms: Lessons from Uber's Global Expansion. Technology in Society, 48, 33-53.

Watanabe, C., Naveed, K. and Neittaanmäki, P., (2017b). Co-evolution between Trust in Teachers and Higher Education toward Digitally-rich Learning Environments. Technology in Society, 48, 70-96.

Wolfslehner, B., Linser, S., Pulzl. H., Bastrup-Birk, A., Camia, A and Marchetti, M., (2016) Forest Bioeconomy - a new scope for sustainability indicators. European Forest Institute. From science to Policy 4.

Yahoo Finance, Amazon Stock Prices. https://finance.yahoo.com/chart/AMZN Retrieved 25 July 2017.

Yahoo Finance, S\&P 500 Index. https://inance.yahoo.com/chart/\%5EGSP Retrieved 28 July 2017.

Yglesias, M.,(2017)The real reason Amazon buying Whole Foods terrifies the competition.https:// www.vox.com/policy-and-politics/2017/6/20/15824718/amazon-whole-foods-profit-margin Retrieved 5 July 2017. 